\title{
Annual General Meeting
}

The 71st Annual General Meeting will be held in the Meeting Rooms of the Zoological Society of London, Regent's Park NW1, on Wednesday July 2nd 1975 at 6 p.m. Mr Peter Archer, QC MP, Solicitor General, will be the guest speaker, and a wine and cheese supper will be served after the meeting.

Agenda

1. Minutes of the Annual General Meeting 1974

2. Presentation and discussion of the Annual Report

3. Presentation and discussion of the Accounts and Auditors' Report

4. Election of Officers

5. Election of Council Members

6. Proposed amendment to Rule 5-Subscriptions: Ordinary members £5 annually

7. Vote of thanks to the Zoological Society of London

Officers and Council

Council recommends that the following members should be re-elected as Officers of the Society for 1975-76:

President Professor Lord Zuckerman OM KCB DSc FRS

Chairman of Council Sir Peter Scott CBE DSC

Vice-Chairman of Council Lord Craigton PC CBE

Honorary Treasurer Ian D. Malcolmson TD

Honorary Secretary Richard Fitter

Council recommends that the following member of Council be elected as Vice-President:

Lt Col C. L. Boyle

Three members of Council retire at the Annual General Meeting and are not eligible for re-appointment for one year:

\section{J. C. Cadbury}

Dr Malcolm J. Coe

Ian S. MacPhail

Council has appointed the following to fill the vacancies and their names are submitted for confirmation:

G. T. Corley Smith CMG

Dr Keith Eltringham

Stuart Johnstone

Hon. Ivor Montagu

Dr John Owen 